Prof. Miroslav Lazić*, LL.D.

ОРИГИНАЛАН НАУЧНИ РАД

10.5937/zrpfn0-24395

Full Professor,

Faculty of Law, University of Niš

Doc. Ivana Simonović ${ }^{*}$ LL.D.

Assistant Professor,

Faculty of Law, University of Niš

UDK: 616-089.843

179

Рад примљен: 12.12.2019.

Рад прихваћен: 09.01.2020.

\title{
THE PRINCIPLES OF HUMAN ORGAN
} TRANSPLANTATION PROCEDURE ${ }^{* *}$

\begin{abstract}
The principles of human organ transplantation procedure must meet two requirements: the requirement of humanity, which all medical activities are based on, and the requirement for patients' protection and the preservation of human and personal rights of every human being, during one's lifetime and after death. In Serbian law, the following principles are established as fundamental ones: the protection of interests and dignity of the organ donor and the organ recipient; voluntarity; medical justification and safety; and equal availability of human organs. Every person having a medically established need and justification for human organ transplantation should be subject to equal conditions for receiving a human organ.
\end{abstract}

Key words: transplantation, consent, ethics, principles.

\footnotetext{
*lazic@prafak.ni.ac.rs

*ivana@prafak.ni.ac.rs

** The paper is the result of research conducted within two research projects: the project Harmonizing the Law of the Republic of Serbia with the European Union Law, run and financed by the Faculty of Law University of Niš; and The Protection of Human and Minority Rights in European Legal Area (179046) run by the Faculty of Law, University of Niš, and financially supported by the Ministry of Education, Science and Technological Development of the Republic of Serbia.
} 


\section{Introduction}

Development of medicine and transplant surgery, where diseased organs are replaced by transplantation from other live or deceased (cadaveric) organ donors, requires solving an array of ethical and legal issues. "Ethical and legal issues arising within the context of new knowledge in these sciences and in the course of their application in the area of experiments on man, genetic engineering, organ transplantation or human assisted reproduction cannot be resolved with the current legal regulations any longer. Legal regulation of these domains is set as a priority task [...] marking this regulation as biolaw [...]" (Kandić-Popović, 1999: 1, 2).

Organ transplantation is ethically debatable; thus, it must be founded on transparency of procedures and exactness of information of significant data. Healthcare institutions and social organisations involved in transplantation must act responsibly and citizens (potential organ donors) must be well acquainted with this humane act. It is primary in transplantation to find organ donors, whose "acting is characterised primarily by a highly exalted act of mercy, and only in the second place it has the legal meaning of donating" (Radišić, 2008: 107).

The issue of organ transplantation is also an object of interest of religion. Unlike Greek and Russian orthodox churches, which officially adopted and publicised the bases of their bioethical teachings ${ }^{1}$, the Serbian Orthodox Church (the SOC) has no officially formulated stands on bioethical problems; there are only comments of certain authors (Andrejić, 2016: 23). The stands within the framework of the SOC on organ transplantation are positive as people's lives can be saved, which is confirmed by the blessing and invitation to believers to bequeath their organs. Patriarch Irinej also published a text confirming "that the issues regarding human organ transplantation are regarded by the Orthodox Church and the Roman Catholic Church, and the traditional Reformation churches in the same way" (Irinej, 2011: 1).

Worldwide, the need for organs for transplantation significantly exceeds the number of donors and the waiting lists are very long. Serbia is not an exception, and statistics show that it is among the last countries in Europe when it comes to the number of performed transplantations. The reasons are numerous; in particular, the citizens' awareness of the significance of transplantation is insufficiently developed; there is also distrust in institutions, as well as preju-

1 The Greek Orthodox Church and the Russian Orthodox Church have almost identical positions on some donorship issues; for example, they both treat donorship as a manifestation of love and empathy; life of one person must not be shortened in order to prolong the lifespan of another one; the system of a presumed consent of potential donors is considered unacceptable; donorship must not entail any financial interest (Andrejić, 2016:25). 
dices about possible abuse of taken organs, etc. Thus, there is a need to inform the citizens better, to raise their awareness about this issue, to generate trust in healthcare system, and to ensure a correct application of medical standards and legal norms on organ transplantation.

In Serbia, the issues significant for organ transplantation are regulated by the Human Organs Transplantation Act of 2018 (hereinafter: HO Transplatation Act). ${ }^{2}$ It also lays down the principles on organ transplantation procedure, which will be analyzed in this paper.

Principles are general norms setting the permitted legal framework for human organ transplantation, but they also have an ethical dimension for the purpose of preserving human integrity and dignity of each subject in organ transplantation procedure. According to the Human Organs Transplantation Act (2018), the transplantation procedure is based on the principles of protection of interests and dignity, voluntarity, charity, medical justification and protection, and equal availability of human organs in Serbia (Articles 4-7 HO Transplantation Act). These principles are general (valid for both the donor and the recipient) whereas the significance of some of them may be more prominent for one or the other party.

\section{0rgan Transplantation}

The law defines organ transplantation as a medical procedure intended for reestablishing certain bodily functions of an organ recipient by replacing it with a donor's organ (Article $3 \mathrm{HO}$ Transplantation Act). ${ }^{3}$ Legally speaking, and bearing in mind that it is forbidden to acquire any material benefit by organ transplantation (non-chargeability rule) ${ }^{4}$, transplantation is based on an act of donation ${ }^{5}$ of the donor's nonrenewable organs and tissues for the purpose of placing them in an organ recipient (a third person) or the donor himself. "In transplantation, the focus is on the protection against any risk for the organ donor, and organ

2 Zakon o presađivanju ljudskih organa (Act on Transplantation of Human Organs), Službeni glasnik Republike Srbije, br. 67/2018; (hereinafter: Human Organs Transplantation Act, HO Transplanation Act, or HOT Act).

3 Article 3 para. 1 item 11 of the Human Organs Transplantation Act.

4 The compensation of material loss incurred by the donor in relation to transplantation is not considered forbidden material benefit. The HO Transplanation Act envisages a compensation of lost profit during the temporary inability to work and an excessive damage sustained by taking one's organ, and a justified compensation for healthcare and technical services related to the transplantation (Art. 5 para. 3 of the HO Transplantation Act).

5 "Donating an organ is not an ordinary civil law contract of donation, as parts of human body are not a thing in free legal trade, but it is a sui generis contract within the rights of personality aimed at treatment of the organ recipient." (Radolović, 2014: 107) 
trafficking is explicitly forbidden, as it would put the donor in a state of extortion for material benefit, which is contrary to the organ donation itself being highly evaluated as a priceless example of altruism" (Mujović-Zornić, 2013: 5).

In organ transplantation, it is most important is to ensure a sufficient number of organ donors. Organ transplantation procedure implemented by an adequate medical institution is regulated in different ways, depending on whether the donor is a living person or a deceased one. The organ transplantation principles are valid, with certain specificities, for all donors.

a) Removal of organs or tissues from living donors may be carried out solely for the therapeutic benefit of the recipient and if there is no suitable organ or tissue available from a deceased person (cadaver) and no other alternative therapeutic method of comparable effectiveness (Convention of Human Rights and Biomedicine, Art. 19 para. 1) ${ }^{6}$

In addition to medical requirements for transplantation, it is also necessary to satisfy legal requirements referring to the donor's and the recipient's competencies for judging and declaring their relevant wills related to their consents for donating organs. Legal rules should ensure the observance of their autonomy, their rights to self-determination and bodily integrity, and enable them to freely express their will whether they want to donate or to receive an organ for treatment. According to the Human Organs Transplantation Act, a living organ donor must be an adult person of full legal ${ }^{7}$ capacity (Art. 17 para. 1 item 1 HO Transplantation Act) who is required to provide a written consent, as an expression of free will that he/she understands the nature, purpose and duration of the intervention, and that he/she has been sufficiently informed in advance about possible risks and expected successful outcome of the intervention (informed consent) (Art. 17 para. 1 item 2 HO Transplantation Act). It excludes children as donors as well as adult persons fully deprived of legal capacity. Besides the incapability of judgement, giving a reasonable and valid declaration may also be prevented by some physical reasons (e.g. the patient's unconsciousness). When making a decision on behalf of another person, the "best" interest of the person should be assessed and protected. The problem is legally eliminated by allowing the legal representatives (husband, adult child, parent) to decide, or by establishing a professional and ethical team for making a decision related to donating organ after one's death, and under a presumed consent. Under the

6 CoE Convention for the protection of Human Rights and Dignity of the Human Being with regard to the Application of Biology and Medicine: Convention on Human Rights and Biomedicine, ETS No.164, Oviedo, 4.4.1997; https://www.coe.int/en/web/conventions/ full-list/-/conventions/treaty/164

7 In this paper, legal capacity implies both the capacity to hold rights and the capacity to exercise them autonomously. 
principle of urgency, it is also possible to pursue the decision of the court which interprets the will of a deceased person in accordance with his/her best interest. ${ }^{8}$

b) Organ removal from deceased persons should prevail since this procedure precludes the risk of any potential threat to the health of living donors. The basic legal and ethical issues of cadaveric organ transplantation are: establishing the moment of death of a potential donor, respecting the deceased person's expressed will, and respecting the family members' piety.

The first phase is establishing the death of a potential donor, which is done by licensed healthcare institutions. The moment of death is established according to the criterion of brain (neurological) death, which occurs with the cessation of brain activities. By establishing this criterion, the application of advanced medical technology for maintaining blood circulation and functions of individual organs after brain death has occured, thereby increasing the number of organs for transplantation. In Serbia, the moment of death is determined under the Rulebook on Medical Criteria and Procedure for Establishing Death of a potential organ donor (Art. 3, 4 of the Rulebook). ${ }^{9}$

Organ transplantation is based on consent. The ethical and legal dilemma is caused by the conflict of the principle on understanding human life as the greatest value and the principle of inviolability of a dead body (cadaver). Under the Oviedo Convention on Human Rights and Biomedicine (1997), there are two possible legal approaches to the consideration of consent to organ transplantation 1) removal of organs only on the basis of an informed express consent given during lifetime (opt-in procedure, i.e. conscious involvement in the register of people who want to donate their organs after death), or 2) the principle of a presumed consent, where a person must sign a legal document stating that he/she opposes the removal of organs from his/her body after death (opt-out procedure). The system of express consent narrows down the circle of potential organ donors. Danmark, Germany, the Netherlands, Switzerland, Australia, and the USA have such a solution, entailing the possibility that consent may be granted by the deceased's relatives, unless the deceased person explicitly stated his/her will thereof. The system of presumed consent, where the will was not explicitly stated during one's lifetime, entails a presumed approval; this practice is common in

8 Sometimes the court is the most objective authority since parents, for example, may be interested in saving the life of another child, while the medical commission is interested in implementing the transplantation procedure. When it comes to children, the possibility of letting the Court decide should be taken into consideration, particularly if there is a disagreement among the kins.

9 Pravilnik o medicinskim kriterijumima, načinu i postupku utvrđivanja smrti lica čiji se deo tela može uzeti radi presađivanja (Rulebook on Medical Criteria and Procedure for Establishing Death of a potential organ donor), "Sl. glasnik RS", br. 31/2005 
the majority of the European Union countries, including Croatia. The Croatian Act on Transplantation of Human Body Parts for Medical Treatment Purposes (Art. 17) enables removing the organ from a deceased person, unless "the deceased person made a written statement of being opposed to organ donation." ${ }^{10}$ Croatia, which is a member of Eurotransplant that coordinates the cross-border transplantation organ exchange, also introduced a non-donor registry.

In January 2017, Serbia became an associate member of Eurotransplant; in order to aquire full membership, Serbia must meet specific requirements (e.g. ten donors per million citizens, compliance with standard procedures, etc.). For the purpose of increasing the number of donors, a presumed consent is established in Serbian law; however, if there is no an explicit statement of the deceased person, his/her family members may disagree. Under the Human Organs Transplantation Act (2018), "Human organs from a deceased person may be removed for transplantation if an adult donor who has full legal capacity did not oppose it, orally or in writing, during his/her life, or if his/her parent, spouse, cohabitee, or an adult child of the deceased does not explicitly oppose it. In derogation of paragraph 1 of this Article, if the deceased person has no relatives referred to in paragraph 1 of this Article, human organs from the deceased person may be removed unless a lateral kin up to and including the second degree of kinship explicitly opposed it at the moment of death (Art. $23 \mathrm{HO}$ Transplantation Act.)

As the presumption of consent is not clearly confirmed, the 2018 HO Transplanation Act has little effect. Therefore, the number of organ donors has not increased. Another factor that contributes to such a sistuation is insufficient awareness on the significance of transplantation. It would be more expedient if the decision on organ donation is made during lifetime and communicated to the authorized public institution (e.g. selected physician who would enter it into the patient's medical record or record the decision in a donor registry) and to his/her family members. The affirmative approach to organ donation demands a well-contemplated work of teams formed to address issues related to organ transplantation for medical treatment purposes, providing permanent education and information to citizens, and raising public awareness about the need for interpersonal solidarity and humanity. The positive attitude of religion, increased trust in healthcare institutions, and fairness in the organ transplantation procedure may contribute to the positive decision on organ donation.

Non-compliance of regulations related to organ transplantation in various states creates a "legal vacuum" and allows for abuses (e.g. transplantation tourism and

10 Zakon o presađivanju ljudskih organa u svrhu liječenja Republike Hrvatske (The Act on Transplantation of Human Body Parts for Medical Treatment Purposes), "Narodne novine", br. 144/ 2012. 
illegal organ trafficking). Although the World Health Organisation condemned the sale of human organs for transplantation purposes, ${ }^{11}$ illegal trafficking will still take place.

\section{Development of medical, ethical and legal principles}

The principles of organ transplantation procedure are derived from the fundamental ethical principles in medicine, which are binding for all medical practitioners. Respecting the patent's dignity, autonomy and privacy, his/her bodily and mental integrities, nonmaleficence, charity, justice (prohibition of discrimination on any basis and fair distribution of insufficient healthcare services) are basic commandments underlying the sensitive relationship between a physician and a patient, scientific researchers and human subjects who participate in biomedical experiments. They are established by numerous international and regional documents (e.g. European Union acts) and they primarily express common consent of medical practitioners on the governing principles that they should be guided by in their everyday work, which are perceived not only as a moral category but also as binding rules. ${ }^{12}$

The Universal Declaration on Bioethics and Human Rights $(2005)^{13}$ is perhaps the most influential international document that establishes the common principles and rules for resolving moral dilemmas prompted by development of medicine. In fifteen bioethics principles ${ }^{14}$, the Declaration stipulates the basic values which should guide scientific and technological development and responsible approach to bioethics, particularly by taking into account human dignity and human rights,

11 "Organ trafficking and transplant tourism violate the principles of equity, justice and respect for human dignity and should be prohibited." (Principle 6 of the Declaration on Organ Trafficking and Transplant Tourism, the Transplantation Society (TTS), and the International Society of Nephrology (ISN), Istanbul, 30 April - 2 May 2008, https://www. declarationofistanbul.org/images/Policy_Documents/2008_Edition_of_the_Declaration_ of_Istanbul_Final.pdf (p. 4).

12 Medical ethics, as a field of applied ethics, studies the rules of behaviour of medical practitioners and provides guidelines for solving moral dilemmas on right and wrong, allowed and forbidden, good and bad, not only for the patient but also for the social community (Kaličanin, 1999: 1).

13 The Universal Declaration on Bioethics and Human Rights (2005), United Nations Educational, Scientific and Cultural Organisation, UNESDOC Digital Library; https://unesdoc. unesco.org/ark:/48223/pf0000146180

14 Bioethicists reflect on the ethical principles which should guide the development of science and ensure the greatest welfare of individuals, humanity and the world at large. They urge for sustainable scientific progress, which will not be inhibited by an excessive legal intervention but will not jeopardise the most significant human and social values. 
welfare, autonomy and consent, personal integrity, privacy and confidentiality, solidarity and cooperation, equality, etc.). ${ }^{15}$

Acting in accordance with good clinical and scientific and research practice is also prescribed in other documents, adopted before and after the 2005 Universal Declaration on Bioethics and Human Rights. The Hippocratic Oath is commonly referred to as the source of moral guidelines in medicine. The contemporary version of this pledge, which physicians take when entering into the medical profession, is found in the Geneva Declaration of the World Medical Association (1948), ${ }^{16}$ whereby practitioners commit to perform their profesional duties with due respect for human life, wellbeing and humane aims of medicine.

The first contemporary set of ethical principles governing research on human beings was established by the Nuremberg Code $(1947)^{17}$. It was formulated as a set of ten principles which were the foundation for establishing the rules of humaine conduct not only towards the persons participating in medical research but also towards any beneficiary of healthcare services. These principles were further developed in declarations and conventions passed later but this Code is significant because it established the standards of an informed consent, including the requirement "to explain to human subjects the nature, purpose and duration of the experiment, method and means to be used, inconveniences and risks that may be expected by them and effects upon his/her health or bodily integrity" (Simonović, 2012:306).

The Helsinki Declaration on ethical principles for medical reserach involving human subjects (1964) ${ }^{18}$ was adopted at the $18^{\text {th }}$ session of the World Medical Association in 1964. The obligations from the Geneva Declaration (1948) and the International Code of Medical Ethics (London 1949) were supplemented with rules (recommendations) for physicians dealing with clinical trials. The Helsinki Declaration was amended in 1975 (at the 19th session of the World Medical Association, in Tokyo), by introducing recommendations for the medical community conducting biomedical research involving human beings.

15 For more detail on the significance of this Declaration, see: Simonović, 2012: 312-314.

16 The Geneva Declaration of the World Medical Association (1948) was ammended at the WMA assemblies in Sidney (Australia) in 1968 and in Venice (Italy) in 1983; https://www.wma.net/policies-post/wma-declaration-of-geneva/

17 The Nuremberg Code (1947), available at; https://history.nih.gov/research/downloads/ nuremberg.pdf

18 The Helsinki Declaration on ethical principles for medical reserach involving human subjects (1964), https://www.wma.net/policies-post/wma-declaration-of-helsinki-ethicalprinciples-for-medical-research-involving-human-subjects/ 
The Declaration of Lisbon on the Rights of the Patient (1981) ${ }^{19}$ envisaged that a medical practitioner should act in accordance with his/her conscience and always in the best interest of the patient, respecting the guaranteed patient rights and autonomy, in particular the right to consent to treatment after receiving adequate information. It sets forth the basic rights that medical profession should provide to the patients even when they are not guaranteed by the national law.

Another important document is the CoE Convention on Human Rights and Biomedicine (1997), known as the Oviedo Convention. ${ }^{20}$ "With five additional protocols (on biomedical research, prohibition of cloning, transplantation of organs and tissues, human embryo and foetus, and human genetics), it expresses the essence of European view on biomedicine development, without undesired implications for man. The application of the Convention and its Protocols is intensified with the obligation of periodical reports of the member states and the jurisdiction of the European Court for Human Rights" (Simonović, 2012: 318). In particular, this Convention regulates the position of juvenile persons (minors) lacking capacity to consent and the manner of obtaining consent for medical intervention (Art. 6), as well as the protection of mentally impaired persons subjected to an intervention for treating a mental disorder (Art. 7 HRB Convention).

The development of genetics and progress in deciphering the human genome is also subjected to ethical scruples. The Universal Declaration on the Human Genome and Human Rights (1997) ${ }^{21}$ emphasises the obligation to respect human rights, inherent dignity and human differences when performing research, treatment or diagnostic procedure, irrespective of one's genetic origin and characteristics (Art. 2).

19 The Declaration of Lisbon on the Rights of the Patient (1981) was adopted at the $34^{\text {th }}$ assembly of the World Medical Association in Lisbon (Portugal), and later amended in 1995 (Bali, Indonesia), in 2005 (Santiago, Chile) and in 2015 (Oslo, Norway); https://www.wma. net/policies-post/wma-declaration-of-lisbon-on-the-rights-of-the-patient/

20 Council of Europe Convention for the Protection of Human Rights and Dignity of the Human Being with regard to the Application of Biology and Medicine: Convention on Human Rights and Biomedicine, ETS No.164, known as the Oviedo Convention (adopted by the Committee of Ministers in November 1996, opened for signature by the CoE in Aprl 1997, and entered into force in December 1999); available at https://rm.coe.int/168007cf98

21 The UNESCO Universal Declaration on the Human Genome and Human Rights (1997), adopted in November 1997; http://portal.unesco.org/en/ev.php-URL_ID=13177\&URL_ DO=DO_TOPIC\&URL_SECTION=201.html 
In Serbia, the principles of medical research are also regulated by the Good Clinical Practice Guidelines in Clinical Research $(2017)^{22}$ and the rulebooks that are in line with the adequate European Union guidelines and recommendations. Setting up ethical committees or boards in all medical and research institutions ensures the control in the application of these principles.

"Development of sciences on living systems (life sciences) has contributed that human rights, such as the rights to bodily integrity, dignity or privacy acquire new dimensions. Parts of human body are used in transplantation, removed organs may be a source for patenting new cell lines without the consent of the person they belong to, and human body entirely represents a potential object of biomedical researches. Such possibilities imply new dimensions of the human right to bodily integrity and the need to clearly define positions of the person who, for instance, gives a part of his/her body for a therapeutic goal or participates in a venture that has no therapeutic character for him/her" (KandićPopović, 1999: 32).

\section{Principles of transplantation procedure}

The Directive of the European Union on standards of quality and safety of human organs intended for transplantation $(2010 / 53 / \mathrm{EU})^{23}$ lays down the rules to ensure quality of organs and safety of the donor and the recipient, irrespective of where they live. It was passed in 2010, with the obligation of the Union members to incorporate it into their national legislations by 2012. The criteria from the Directive should also be observed by other European Union-oriented countries.

The Serbian Human Organ Transplantation Act affirms the generally accepted principles of not only transplantation medicine but also medicine in general. These principles are as follows: protection of interest and dignity; voluntarity and charity; medical justification and safety; and equal availability of organs.

\subsection{Principle of the protection of interest and dignity}

The principle of the protection of interest and dignity imposes that the priorities in organ transplantation are the preservation of life and health and the protection of fundamental human rights and dignity of organ donors and recipients (Art. 4

22 Smernice dobre kliničke prakse u kliničkim istraživanjima (Good Clinical Practice Guidelines in Clinical Research), Službeni glasnik RS", br. 108/2017, http://www.pravnoinformacioni-sistem.rs/SlGlasnikPortal/eli/rep/sgrs/ministarstva/drugiakt/2017/108/1/reg 23 Directive 2010/45/EU of the European Parliament and of the Council of 7 July 2010 on standards of quality and safety of human organs intended for transplantation, OJ L 207, 6.8.2010, p14-29, abailable at https://eur-lex.europa.eu/legal-content/EN/ ALL/?uri=CELEX\%3A32010L0053 
of the HO Transplantation Act). Organ transplantation is indented to prolong the life of the organ recipient, but the intervention may affect the pshyco-physical integrity of both the recepient and the donor. Bearing in mind that the number of possible organ donors is always lower than the persons in need of an organ, it is necessary to construe socially and ethically acceptable organ transplantation procedure, which will ensure respect for one's personality and protection of one's most significant personality rights.

Protection of dignity provides autonomy of decision making of organ donors and recipients in each phase of organ transplantation procedure. More broadly, a consistent application of this principle should guarantee a fair allocation and availability of organs, free of charge and irrespective of one's financial standing. This principle is in accordance with the human right to dignity acknowledged by the Universal Declaration on Human Rights, requiring respect for dignity of every human being without discrimination of any kind (Art. 1 and 2 UDHR). Organ trafficking is directly opposed to the request for respecting human dignity; thus, it is prohibited by international conventions which, despite their significance, are not generally accepted. This contributes to the existence of the black market and the so-called "transplantation tourism" in countries with undeveloped transplantation systems.

The right to protection of dignity is enjoyed not only by the organ recipient but also by the donor, regardless of whether he/she is alive or a deceased person. If a deceased person is the donor of organs, tissues or cells, it is necessary to respect his/her will regarding organ donation explicitly expressed during his/ her lifetime; in case there is no such statement, the deceased person's dignity is protected by the will and piety of his/her family members. Therefore, a presumed consent on organ donation for transplantation must be preceded by appropriate information on the consequences of silence, i.e. not giving a statement on donation during one's lifetime. We believe that removing an organ may not only be based on a presumed will; there is no need for the family members to give their approval if the deceased did not consent during his/her lifetime. A failure to make a statement should not be considered as (presumed) consent, particularly in the contemporary age of frequent sudden deaths in traffic and other accidents and sudden diseases with fatal outcomes (heart attack, etc.).

\subsection{Principle of voluntarity and principle of charity (benevolence)}

Voluntary written consent of the organ donor and the organ recipient, and benevolent (charitable) organ donation free of charge (without receiving any remuneration or attaining any material benefit) are two important components on which organ transplantation rests. These are two autonomous principles 
although Serbian law regulates them in the same article (Art. 5 HO Transplantation Act).

The voluntarity principle implies that human organs donation is performed on the basis of freely expressed and legally relevant will of an adequately informed donor. Voluntarity also means the right to change one's opinion and revoke one's consent, as long as it is possible considering the phase of medical intervention. The voluntarity principle entails an expression of free will, which is one of the basic principles of contract law and, hence, of an organ transplantation contract. "From the legal viewpoint, it is a contract based on donorship but, being an act of charity and compassion, it entails high ethical components that make it quite different from a traditional trade contract" (Mujović-Zornić 2013: 5).

Freely expressed will must be a result of being well informed and thoughtful, which refers to the organ donor and the organ recipient alike. The right of an individual to autonomously makes decisions relevant to his/her psycho-physical integrity are not only part of European culture and civilisation but also a legal principle of freedom of decision-making of a capable person. The system of autonomous decision-making is contrary to the so-called paternalistic system where physicians make decisions on transplantations. For an individual's "informed consent" to be legally valid, the statement has to be made freely, without third persons' pressure; it has to be made by a capable person who understands the consequences of such a decision and who is informed about the relevant medical facts that are important to assess the risk to the patient. The necessary consent must have been given expressly and specifically in written form (Art. 19 Convention on the Human Rights and Biomedicine).

"It is commonly believed that the principle of autonomy is fulfilled if capable adults have given their consent on the basis of being informed on all the risks that may occur when, for example, their organ is removed for transplantation (informed consent)" (Kandić-Popović, 1999:33). The principle of autonomy of will is embodied in the freedom of every person to make decision on a medical treatment and the obligation of medical practitioners to respect that decision. It is the patient's right to refuse the treatment, and the physician cannot assess whether the reasons for such a decision are rational. However, it also implies that the patient has been adequately informed on the facts important for the decision.

"A person is autonomous if she/he is capable of understanding the essence and significance of facts, values and other factors on the basis of which he/she makes decision, and understanding the consequences of his/her decisions and accepting them" (Simonović, 2012:301). A physician is obliged to provide the necessary and full information to the patient on the disease, on the purpose and nature of transplantation procedure, likelihood of success, possible risks and negative 
consequences and anything else needed for making decision on the medical treatment. The conversation should be made in a comprehensive terminology, adapted to the patient's intellectual level. The information on the right to revoke or to withdraw the previously granted consent (before the completion of the medical intervention), without any need to explain such a decision, is an integral part of each validly made conversation between the physician and the patient, or the organ recipient and the organ donor.

In accordance with the principle of charity (benevolence), the legal basis for organ transplantation is a gratuitous contract, without pecuniary or any other material benefit being given or taken in return (Art. 5 of the HO Transplantation Act); the Act only permits the compensation of reasonable costs. ${ }^{24}$ In this sense, organ trafficking is criminally sanctioned trade, and advertising of healthcare institutions is prohibited, as well as the sale and purchase of organs. The UN Convention against Transnational Organized Crime (2004) and the Protocol to Prevent, Suppress and Punish Trafficking in Persons, Especially Women and Children (2000) explicitly condemn sale and purchase of organs (Art. 1). ${ }^{25}$ Legal prohibition of human organs trafficking is based on the Convention on Human Rights and Biomedicine (1997) which provides that "The human body and its parts shall not, as such, give rise to financial gain" (Art. 21 of the Convention).

The standpoint on gratuitousness of donating an organ for transplantation is prevailing, but there are also opinions that the benevolence principle should be abandoned and such contracts should legally be "considered to be commercial contracts, even if they are sui generis, and also legitimate from the ethical and legal viewpoints [...] since disposition of human organs, as sui generis things, by its legal nature is an agreement regulated under contract law rules" (Klajn-Tatić, 2007: 331). In professional public, there are also opinions that a sort of strictly controlled commercialization of organ donation for transplantation should be allowed, whereby to exclude any immediate covenant and mediators (IvančićKačer, 2012: 452). It is correct that the autonomy of will also includes the donor's

24 This exception refers to: "1) the compensation of earnings to the live donor of human organ during the period of the insured person's temporary incapacity to work, which has been caused by removal or transplanatation of a human organ transplantation; 2) a reasonable and justified compensation for the payment of healthcare or technical services related to the removal of a human organ, including the transportation of the deceased person who was moved to another healthcare institution beyond the deceased person's place of residence for the purpose of a possible human organ donation; and 3) the compensation in the event of excessive damage incurred as a consequence of removing a human organ from a live donor (Art. 5 of the HO Transplantation Act).

25 One of the earliest passed laws was the US National Organ Transplant Act (NOTA) of 1984 which explicitly prohibits pecuniary compensation for donated organs, which is often challenged (Diamond, 2012:1). 
right to make decisions on the character of agreement on the basis of which he/ she donates his/her organ. However, besides violating the ethical principles, .organ trade (either free or controlled) would certainly have some drawbacks; for example, abandoning the principle of solidarity and humanity would diminish altruistic organ donation; it would diminish or exclude the opportunities for poor people to be cured by using the organ transplantation method; the poor would see the possibility in organ trade for obtaining income for themselves and their family members, which entails the danger of abuse; the established control over the organ trade would not be appropriate, and it would hardly eliminate the black market; it would be difficult to ensure a just allocation of organs if it is conditioned by payment; human civilisation would experience another defeat of humanity before the onslaught of economic interests, etc.

The issue of respecting the autonomy of will of juvenile persons is also highly debatable. Can the minor's parents or legal representatives take the risk of granting consent on behalf of the child who is either an organ donor or a recipient, or consent to getting the child involved in the experiment? A strict respect of the autonomy principle requires that every person first must consent to any action related to his/her bodily integrity. It is commonly believed that, even when juveniles are organ donors, they should be given the opportunity to make a statement on their consent to or rejection of the intervention. "In the event of an explicit rejection, the juvenile person's will should be acknowledged, which is the best indicator of respecting the autonomy of will of those who do not have any legal capacity in legal sense" (Kandić-Popović, 1999: 36). We consider that, in such cases, juvenile persons should have a special legal capacity; thus, prior to the age of majority, they should be asked for consent, depending on the type of intervention and the degree of risk.

The principle of voluntarity is also reinforced in the Code of Medical Ethics of the Serbian Medical Chamber that provides that "a physician is obliged to respect the rights, freedoms, autonomy and human dignity of each patient. The obligation of respecting human dignity does not cease even after the death of patient" (Art. 6 of the Medical Ethics Code).

\subsection{The principle of medical justification and safety}

The principle of medical justification and safety implies that a transplantation intervention is only performed if it is the most convenient treatment method, in accordance with the medical profession rules, professional and ethical standards and obligations. The transplantation method must be in compliance with contemporary scientific achievements, and conducted in a manner and under 
conditions that decrease the risk for the recipient and the risk of human organs loss (Art. 6 of the HO Transplantation Act).

"Besides the autonomy principle as the fundamental principle from the viewpoint of respecting the right to bodily integrity and dignity of an individual, regarding the removal of an organ, tissue or a cell, as well as regarding an experiment, two related principles are often set out: the principle of doing good (beneficence) and the principle of not doing harm (nonmaleficience). According to the explanation given by the American National Commission, the principles include the two following rules: not doing or minimizing harm, and maximizing a potential benefit" (Kandić-Popović, 1999: 37).

Organ transplantation must be medically justified. It includes taking into consideration the balance between the risk for the subjects (primarily for a live donor, but also for the organ recipient) and the expected benefit that the transplantation interventions may bring. The risk must be minimal or non-existing, and the expected benefit must be real. The physician should stop the intervention that unexpectedly proves to be risky for one or more participants.

Additionally, the Hippocrates' proverbial saying Primum non nocere (First, do no harm) obliges practitioners to exercise humanity in a physician-patient relationship. This principle was primarily created to prohibit infliction of physical pain but, in contemporary law, it also refers to the protection against inflicting mental anguish. As there are no two identical patients in medical practice, the physician must adjust his/her conduct to each patient, considering first of all the patient's interest but also the justification and safety of the medical intervention. An experimental transplantation must meet all the legal requirements and the medical science and profession rules.

\subsection{The principle of equal availability of human organs}

The principle of equal availability of human organs implies that every person having a medically established need and medically justified reasons for human organ transplantation should be entited to receive a human organ under equal conditions; it also entails equal requirements for entering the organ recipient's name into the national organ transplantation register of persons waiting for organ transplantation (Art. 7 of the HO Transplantation Act). This provision is aimed at preventing any discrimination and abuses regarding organ availability.

Eurotransplant ${ }^{26}$ is a non-governmental organization that coordinates the crossborder exchange of organs for transplantation in the territories of the member

26 Eurotransplant is organized and functions on the basis of the democratic principle. It includes the Assembly, the Management Board, the Advisory Council, and nine Advisory 
countries (Austria, Germany, the Netherlands, Luxembourg, Belgium, Slovenia, and Croatia); on the basis of cooperation agreements between the member countries, it provides a transparent and objective selection system and ensures optimal utilisation of available organs for transplantation.

In line with medical standards and for medically justified reasons, every person who has been entered into the national register of persons in need of organ transplantation is entitled to receive a human organ under equal conditions and without discrimination on any grounds. The data on organ recipients are confidential. In organ transplantation, it is necessary not only legally but also organisationally to set up a perfect operating system, given the highly limited transplantation time available (heart and lung must be transplanted within 4 hours, kidney- within 24 to 36 hours, pancreas- within 12 to 18 hours, and liver- within 8 to 12 hours).

In comparative law, organ availability is associated with the principle of justice (fairness). "According to the interpretation of the US National Commission, the justice principle particularly implies the protection of weaker, more vulnerable subjects. It does not mean that they should be deprived of the opportunity to participate in an experiment that would be beneficial for a specific age group (e.g. children) or entire population. This principle is particularly significant in the context of transplantation. Considering the conflicting circumstances (scarce organ supply as opposed to urgent demand of a large number of potential recipients), social protection ethics requires equally fair and just relation to the disease" (Kandić-Popović, 1999: 38).

We believe that organ sales should not be legalised as rich patients would be privileged, and thus the equality principle would be infringed. The Convention on Human Rights and Biomedicine protects the dignity and identity of all human beings and guarantees everyone, without discrimination, respect for their integrity and other rights and fundamental freedoms with regard to the application of biology and medicine (Art. 1). Physicians also contribute to the observance of the principle of justice and equal availability of organs by doing their job in a conscientious and professional manner, without discrimination of any kind as to age, race, sex, religion, political opinion, sexual orientation, smoking habits, obesity, financial status, or any other source of inequality. "Ethically, it is unac-

Commissions. There is a single central donor identification system and a single waiting list, with approximately 15,000 patients. When a donated organ becomes available, the computer programme generates the compatibility (match) list for each organ. Four general principles are decisive for allocating an organ: the chance of successful transplantation outcome; the urgency of transplantation established by experts; the waiting time, and the so-called national organ transplant account balance (in the exchange of organs between countries). For more, see: https://www.eurotransplant.org/cms/index.php?page=about_brief 
ceptable that a physician refuses any examination or treatment based on his/her non-approval of the patient's way of life" (Salihbegović, 2008: 43).

\section{Conclusion}

The contemporary world is characterised by dynamic development, permanent reviewing and changes of many values of previous generations. Moral principles are not exempted from change. With the development of science and technology, new methods of treatment are introduced, inter alia, organ transplantation and experimental interventions, which may jeopardise human dignity and integrity. Ethics has always been a companion of medical professionals, considering that knowledge without conscience and morality, particularly in medicine, may be counterproductive and may endanger personal and other rights of the patient. Therefore, it is necessary to set up precise ethical and legal frameworks of freedom for participants of numerous medical interventions, particularly when applying organ transplantation methods from live and deceased persons to the receiving patient for the purpose of treatment. Organ transplantation is based on the act of donation, which is an expression of human solidarity and humanity, and not purely a legal act of donation or sales and purchase.

Medical professionals and potential organ donors and organ recipients are confronted with numerous ethical and legal dilemmas. As its direct object is a person, his/her life, health and dignity, the medical profession has specific ethical rules, which are also subject to consideration under substantive and procedural law. These ethical rules must be legally shaped, not be left to the autonomy of will and conscientiousness of subjects during transplantation procedure.

The principles of organ transplantation provide the legal framework for legal regulations. In Serbian law, they are: the principle of protection of interests and dignity of the organ donor and the organ recipient (preservation of life and health of subjects, and respect for their personal rights have the priority); the principle of voluntarity and charity (donation of human organs is based on freely expressed will of fully informed organ donor and organ recipient on the benefits and possible risks; it is performed without compensation - as a gift); the principle of medical justification and safety (transplantation interventions are only performed if it is the most convenient method of treatment, in the way that decreases the risk for the recipient without jeopardising the organ donor's life); the principle of equal availability of human organs (prevention of discrimination and abuse regarding organ availability). Every person who is deemed to have a medically established need and medically justified reasons for human organ transplantation should have a prospect to receive a human organ on equal basis with others. In order to prevent any discrimination and possible abuse, the or- 
gan recepient is entered into the national register of persons waiting for organ transplanation (waiting list).

Although an organ donation is based on a (donorship) contract, it is not a gift (donatio) in classic terms, due to the prevailing ethical elements of humanity, charity and solidarity. Therefore, it is important to set up the legal framework and principles which organ transplantation procedure is to be based on, and to regulate all the phases of this procedure in detail. Certainly, at the current level of ethical comprehension of life and death, the principle of charity should remain binding, as well as the prohibition of organ trafficking.

\section{References}

Andrejić, Ana (2016). Stavovi o bioetičkim pitanjima u okviru srpske pravoslavne crkve u kontekstu pravoslavne bioetike, Godišnjak za sociologiju Filozofskog fakulteta u Nišu, br. XII/17, str. 23-45.

Diamond, J. Nicholas (2012). Is it Time to Reconsider the National Organ Transplant Act? Science Progress, posted 16.07.2012, available at: https://www. scribd.com/document/339030243/Is-It-Time-to-Reconsider-the-National-Organ-Transplant-Act-Diamond-2012/

Irinej, B. Episkop novosadski i bački, Ukratko o transplantaciji, Srpska pravoslavna crkva, (posted 26. 01 2011), available at: http://spc.rs/sr/ukratko_o_ transplantaciji;

Ivančić-Kačer, B, (2012). Pravni promet ljudskim organima, Pravni život, br. 9, str.451-466.

Kaličanin, P. (1999). Medicinska etika i medicinsko pravo. Beograd: Institut za mentalno zdravlje.

Kandić-Popović, Zorica (1999). Pravna zaštita osnovnih ljudskih vrednosti u Centralnoj i Istočnoj Evropi i moderna biotehnologija, ka evropskoj harmonizaciji, Budimpešta; available at http://docplayer.net/34196549-Pravna-zastita-osnovnih-ljudskih-vrednosti-u-centralnoj-i-istocnoj-evropi-i-moderna-biotehnologija-ka-evropskoj-harmonizaciji-zorica-kandic-popovic.html,

Klajn-Tatić, V. (2007), Etička i pravna razmatranja donorstva inter vivos, Pravni život, br. 9, str.331-346.

Mujović-Zornić, H. (2013). Donacija i transplantacija organa. Beograd: Institut društvenih nauka, str.1-10.

Radišić, J. (2008). Medicinsko pravo. Beograd: Nomos. 
Radolović, A. (2014). Pravni poslovi prava osobnosti, Zbornik Pravnog fakulteta Sveučilišta u Rijeci. Vol. 35 Br. 1, str. 95-118.

Simonović, I. (2012). Bioetika i ljudske vrednosti - ostvarivanje i zaštita principa i prava pojedinaca u oblasti medicine. Zbornik radova Pravnog fakulteta u Nišu. LXIII, str. 297-322.

Turčinović, Filip, Konvencija iz Ovijeda - Evropska povelja o bioetici, (2002) Vol. LIV, br. 1-2, br, 54, pp. 146-157; http://www.doiserbia.nb.rs/img/doi/00258555/2002/0025-85550201008T.pdf

Eurotransplant (in brief): https://www.eurotransplant.org/cms/index. php?page=about_brief; $\quad$ https://www.eurotransplant.org/cms/index.

php?page=pat_croatia

Legal acts

CoE Convention for the protection of Human Rights and Dignity of the Human Being with regard to the Application of Biology and Medicine: Convention on Human Rights and Biomedicine, ETS No.164, Council of Europe, Oviedo, 04/04/1997, available at: https://www.coe.int/en/web/conventions/full-list/-/conventions/ treaty/164

Declaration on Organ Trafficking and Transplant Tourism (2008), the Transplantation Society (TTS) and the International Society of Nephrology (ISN), Istanbul, April 30 to May 2 2008, available at: https://www.declarationofistanbul.org/ images/Policy_Documents/2008_Edition_of_the_Declaration_of_Istanbul_Final. pdf.

Directive 2010/45/EU of the European Parliament and of the Council of 7 July 2010 on standards of quality and safety of human organs intended for transplantation, available at https://eur-lex.europa.eu/legal-content/HR/ TXT/?uri=celex:32010L0053;

Geneva Declaration of the World Medical Association (1948), adopted at the $2^{\text {nd }}$ General Assembly of the the World Medical Association, Geneva, Switzerland, ammended in 1968 and 1983; available at: https://www.wma.net/policies-post/ wma-declaration-of-geneva/

Helsinška deklaracija o etici u istraživanjima sa ljudima (The Helsinki Declaration on Ethical Principles in Medical Research involving Human Beings), prevod Jocić D., Krajnović D., Farmaceutski fakultet, Univerzitet u Beogradu, decembar 2009, available at https://www.docsity.com/sr/helsinska-deklaracija-beleskafarmaceutsko-zakonodavstvo-i-etika-farmacija/368621/; 
International Code of Medical Ethics (1949), World Medical Association, available at https://www.wma.net/policies-post/wma-international-code-of-medicalethics

Kodeks medicinske etike Lekarske komore Srbije (2016) (Code of Medical Ethics of the Serbian Medical Chamber), "Sl. glasnik RS", br. 104/2016; available at https://www.paragraf.rs/propisi/kodeks_medicinske_etike_lekarske_komore_srbije.html

Konvencija ujedinjenih nacija protiv transnacionalnog organizovanog kriminala i dopunskog protokola i Protokol za prevenciju, suzbijanje i kažnjavanje trgovine ljudskim bićima, naročito ženama i decom (UN Convention against Transnational Organized Crime and the Protocol to Prevent, Suppress and Punish Trafficking in Persons, Especially Women and Children), "Službeni list SRJ"- Međunarodni ugovori, br. 6/2001, http://www.tuzilastvorz.org.rs/upload/Regulation/Document__sr/2016-05/konvencija_un_protiv_org_krim_lat.pdf

Lisbon Declaration on the Rights of the Patient (1981) of the World Medicial Association amended in 1995, revised in 2005; available at: http://dl.med.or.jp/ dl-med/wma/lisbon2005e.pdf

Nirnberški kodeks iz 1947 (The Nuremberg Code, 1947), available at https:// history.nih.gov/research/downloads/nuremberg.pdf;

Pravilnik o medicinskim kriterijumima, načinu i postupku utvrđivanja smrti lica čiji se deo tela može uzeti radi presađivanja (Rulebook on Medical Criteria and Procedure for Establishing Death of a potential organ donor), " Služneni glasnik $R S^{\prime \prime}$, br. 31/2005.

Smernice dobre kliničke prakse u kliničkom istraživanju, (Good Clinical Practice Guidelines in Clinical Research), "Služneni glasnik RS", 2008/ br. 28. available at http://www.vet.minpolj.gov.rs/legislativa/pravilnici/Smernice\%20dobre\%20 klinicke\%20prakse $\% 20 \mathrm{u} \% 20$ klinickom $\% 20$ ispitivanju.pdf

The Universal Declaration on Bioethics and Human Rights (2005), UNESCO/United Nations Educational, Scientific AND Cultural Organisation, UNESDOC Digital Library, available at https://unesdoc.unesco.org/ark:/48223/pf0000146180

Univerzalna deklaracija o ljudskim pravima iz 1948 (Universal Declaration of Human Rights, 1948), available at http://www.bgcentar.org.rs/bgcentar/wpcontent/uploads/2013/02/Univerzalna-deklaracija-o-ljudskim-pravima-1948. pdf

Zakon o potvrđivanju Konvencije o zaštiti ljudskih prava i dostojanstva ljudskog bića u pogledu primene biologije i medicine: Konvencija o ljudskim pravima i biomedicini, sačinjena u Oviedu 4. aprila 1997 (Act on the Rartification of the 
Convention of Human Rights and Biomedicine), "Sl. glasnik RS - Međunarodni ugovori", br. 12/2010

Zakon o presađivanju ljudskih organa u svrhu liječenja Republike Hrvatske (The Act on Transplantation of Human Body Parts for Medical Treatment Purposes), "Narodne novine", br. 144/ 2012, available at https://www.zakon.hr/z/556/Zakon-o-presa\%C4\%91ivanju-ljudskih-organa-u-svrhu-lije\%C4\%8Denja

Zakon o presađivanju ljudskih organa (Human Organs Transplantation Act), "Sl. glasnik $R S^{\prime}, 2018$, br. 57, available at https://www.paragraf.rs/propisi/zakon-opresadjivanju-ljudskih-organa.html\#

\section{Др Мирослав Лазић,}

Редовни професор Правног факултета,

Универзитет у Нишу

Др Ивана Симоновић,

Доцент Правног факултета,

Универзитет у Нишу

\section{НАЧЕЛА ПОСТУПКА ПРЕСАЪИВАЊА ОРГАНА}

\section{Резиме}

Начела поступка пресађивања органа морају да испуне два захтева: захтев хуманости, на којој почива медицинска делатност, и захтев заштите пацијената и очувања људских и личних права сваког човека - за живота и након његове смрти. У српском праву, за основна начела утврђена су: заштита интереса и достојанства даваоца и примаоца органа; добровољност; медицинска оправданост и безбедност, једнака доступност људских органа. Свако особа са медицински утврђеном потребом и оправданошћу за пресађивањем људског органа, требало би да добије једнаке услове за добијање људског органа.

Кључне речи: трансплантација, сагласност, етика, начела. 
